\title{
IMMUNOCHEMICAL ANALYSIS OF THE SPECIES SPECIFIC GLYCOPROTEIN OF THE HUMAN RED CELL MEMBRANE
}

\author{
KAZUKO AKIYAMA, TOKUJI INOUE, RYOUICHI TSUDA \\ AND MITSUWO HARA \\ Department of Legal Medicine, Kurume University School \\ of Medicine, Kurume, 830, Japan
}

Received for publication September 24, 1980

\begin{abstract}
Specific antiserum for human red cells was prepared from rabbit antihuman red cell serum by absorbing with red cells of horse, hog, dog and Japanese monkey. This antiserum proved specific for human red cells regardless of blood types $\mathrm{ABO}$ and $\mathrm{MN}$ demonstrated in hemagglutination test.

A glycoprotein was extracted with lithium diiodosalicylate (LIS) and isolated through chromatographic procedures from human red cell membranes and the substance showed inhibitory activity for the specific antiserum as well as for anti-M and anti- $\mathrm{N}$ sera. The isolated glycoprotein corresponded to PAS-1 on SDS-PAG electrophoresis. The inhibitory activity of the PAS-1 for the specific antiserum was lost after the substance was treated with sialidase for $24 \mathrm{hr}$. A moderate reduction of the inhibitory activity for anti-M and anti-N sera but not for the specific antiserum was seen after the treatment for $1 \mathrm{hr}$.

These results indicate that different structures involving sialic acids in the PAS-1 molecule may be responsible for the different susceptibilities to sialidase and these structures may reflect different antigenic determinants.
\end{abstract}

\section{INTRODUCTION}

The species and organ specific proteins in the body fluid have previously demonstrated utilizing antisera prepared for the proteins by immunochemical methods (Hara, 1974). Subsequently, it was found that human red cells possess the species specificity using anti-human red cell serum and the antiserum was applied for the detection of origin of blood stains (Hara et al., 1976).

The presence of the species specific substance of human red cells has previously indicated from the results of hemagglutination and absorption tests using antiserum prepared against human red cells (Kirihama, 1924; Hallen, 1929).

In the present study, human red cells were used in immunization in rabbits and the immune serum was tested with human and animal red cells to find cross-reactivity and following absorption with animal red cells to obtain the specific antiserum. A glycoprotein was prepared from human red cell membranes by a method of lithium diiodosalicylate and chromatographic processes were carried out for further purification. The differences of inhibitory activity of the substance for the specific antiserum, anti-M and anti-N sera were observed and discussed. 


\section{MATERIALS AND METHODS}

\section{Human red cells:}

Human group $\mathrm{O}, \mathrm{N}$ red cells for immunization and group $\mathrm{A}, \mathrm{MN}$ for preparation of the membrane glycoprotein were obtained from the Japanese Red Cross Blood Transfusion Service, Fukuoka, Japan. Blood samples for hemagglutination test were obtained from 2, 453 healthy blood donners.

\section{Animal red cells:}

Red cells of various animals including cow, horse, hog, dog, cat, guinea pig, rat, sheep, mouse, Pan troglodytes (chimpanzee), Macaca fuscata (Japanese monkey), Hylobates lar, Hylobates agilis, Macaca cyclopis, Macaca mulatta, Corpithecus aethiops, Ateles paniscus, Leontocebus oedipus and Cercopithecus aethiops were used for agglutination and absorption tests. Blood of the primates was supplied from the Primate Research Institute, Kyoto University.

\section{Immunization:}

Five $\mathrm{ml}$ of $10 \%$ washed human red cell suspension in saline was injected intravenously into rabbits every other day for 7 injections. Blood was obtained from the rabbits one week after the last injection and sera were separated from the clotted blood.

\section{Preparation of specific antiserum:}

Antiserum specific for human red cells was prepared by absorption of the rabbit immune serum with washed packed red cells of horse, hog, dog and Japanese monkey until no agglutination with respective red cells was observed.

\section{Hemagglutination test:}

The immune sera were serialy diluted in saline and mixed with an equal volume $(0.1 \mathrm{ml})$ of $2 \%$ red cell suspen- sion. The mixture was incubated at room temperature for $1 \mathrm{hr}$ and agglutination was examined after centrifugation at $1,000 \mathrm{rpm}$ for $5 \mathrm{~min}$.

\section{Absorption test:}

An equal volume $(0.2 \mathrm{ml})$ of antiserum was mixed with washed packed red cells or $0.5 \mathrm{mg}$ of the membrane glycoprotein. The mixture was gently shaken at $37^{\circ} \mathrm{C}$ for $30 \mathrm{~min}$ followed further incubation at $10^{\circ} \mathrm{C}$ for $16 \mathrm{hr}$. The supernatant of the mixture after centrifugation at 3,000 rpm for 5 min was subjected to agglutination test for the appropriate red cells.

\section{Hemagglutination inhibition test:}

Serial two-fold dilutions in saline of the membrane glycoprotein treated with sialidase were prepared. Two-tenth $\mathrm{ml}$ of each dilution was mixed with the specific antiserum adjusted to a titer of $1: 8$ and the highest dilution which showed no agglutination was recorded as inhibition titer of the substance. The substance was also used for the absorption test with anti-M and anti-N sera obtained from Ortho Diagnostics, Raritan, N.J., U.S.A.

Preparation of the membrane glycoprotein:

Red cell membranes prepared by the method of Dodge et al. (1963) were solubilized with lithium diiodosalicylate (LIS) according to the method of Marchesi and Andrews (1971). Sepharose 6B column chromatography and DEAEcellulose column chromatography were followed to obtain the glycophorin or PAS-1 (Furthmayr et al., 1975).

Sodium dodecyl sulfate polyacrylamide gel (SDS-PAG) electrophoresis:

PAG (10\%) electrophoresis in $0.1 \%$ SDS was performed according to the method of Weber and Osborn (1969). 
The membrane glycoprotein was incubated at $50^{\circ} \mathrm{C}$ for $4 \mathrm{hr}$ in phosphate buffer containing $0.1 \%$ SDS and $0.1 \%$ mercaptoethanol, and subjected to electrophresis. After electrophresis, gels were stained with amido black for protein and with the Schiff reagent for carbohydrates after being fixed in $25 \%$ isopropanol-10\% acetic acid (Okuyama and Kondo, 1974).

\section{Treatment with sialidase:}

Five $\mathrm{mg}$ of the membrane glycoprotein was dissolved in $1.0 \mathrm{ml}$ of $0.02 \mathrm{M}$ phosphate buffer, $\mathrm{pH} 6.5$, to which $1.0 \mathrm{ml}$ of sialidase solution $(0.5 \mathrm{mg} / \mathrm{ml}$, Cl. perfringens Type V, Sigma, E.C. No. 3. 2. 1. 18) was added and digested at $37^{\circ} \mathrm{C}$ for 1,5 and $24 \mathrm{hr}$ respectively. Two-tenth $\mathrm{ml}$ of the treated materials were used for the determination of sialic acid content by method of Warren (1959) and $0.1 \mathrm{ml}$ aliquots were used for the agglutination inhibition test.

\section{RESULTS}

Characterization of heteroagglutinins of the rabbit sera before immunization:

Heteroagglutinin titers of the rabbit sera before immunization were demonstrated up to $1: 16$ for human, nonhuman primates, rat, mouse, guinea pig, horse, hog, sheep, dog and cat. No agglutination was observed with cow red cells (Table 1 and 2). When the rabbit sera were absorbed with red cells of human, horse, hog, dog and Japanese monkey, it was occasionally found that neither red cells of the animal used as absorbent nor red cells of other animals were agglutinated with the absorbed rabbit sera. However, most of the absorbed rabbit sera still agglutinated red cells of animals except the animals used as absorbent, though the agglutinin titers were less than $1: 4$.

TABLE 1

Heteroagglutinin titer of the rabbit sera against human and animal red cells

\begin{tabular}{|c|c|c|c|c|c|c|c|}
\hline \multirow{3}{*}{ red cells of } & \multirow{3}{*}{$\begin{array}{l}\text { before } \\
\text { immuni- } \\
\text { zation }\end{array}$} & \multicolumn{6}{|c|}{ after immunization with human red cells } \\
\hline & & \multirow{2}{*}{$\begin{array}{l}\text { non- } \\
\text { absorption }\end{array}$} & \multicolumn{5}{|c|}{ absorbed with red cells of } \\
\hline & & & horse & hog & $\operatorname{dog}$ & $\left|\begin{array}{c}\text { horse, hog, } \\
\text { dog }\end{array}\right|$ & $\begin{array}{l}\text { Japanes } \\
\text { monkey }\end{array}$ \\
\hline human & $1-16$ & $\begin{array}{l}4,096 \\
-16,384\end{array}$ & $\begin{array}{l}2,048 \\
-4,096\end{array}$ & $\begin{array}{l}2,048 \\
-8,192\end{array}$ & $\begin{array}{l}2,048 \\
-4,096\end{array}$ & $\begin{array}{l}1,024 \\
-2,048\end{array}$ & $\begin{array}{l}1,024 \\
-2,048\end{array}$ \\
\hline rat & $1-16$ & $16-64$ & $1-4$ & $1-4$ & $1-2$ & $1-2$ & $0-2$ \\
\hline mouse & $2-16$ & $16-32$ & $1-2$ & $1-2$ & $1-2$ & $1-2$ & $1-2$ \\
\hline guinea pig & $1-8$ & $2-128$ & $1-4$ & $1-8$ & $1-4$ & $1-4$ & $0-8$ \\
\hline horse & $0-4$ & $2-128$ & 0 & $0-4$ & $2-8$ & 0 & $1-16$ \\
\hline hog & $0-2$ & $8-128$ & $2-4$ & 0 & $2-8$ & 0 & $1-8$ \\
\hline cow & 0 & 0 & 0 & 0 & 0 & 0 & 0 \\
\hline sheep & $0-2$ & $1-4$ & 0 & 0 & $0-1$ & 0 & 0 \\
\hline $\operatorname{dog}$ & $0-16$ & $2-128$ & $1-4$ & $1-4$ & 0 & 0 & $1-16$ \\
\hline cat & $0-8$ & $2-64$ & $0-4$ & $0-8$ & $0-4$ & $0-2$ & $0-16$ \\
\hline
\end{tabular}


TABLE 2

Heteroagglutinin titer of the rabbit sera against primate red cells

\begin{tabular}{|c|c|c|c|c|c|}
\hline \multirow{3}{*}{ red cells of } & \multirow{3}{*}{$\begin{array}{l}\text { before } \\
\text { immuni- } \\
\text { zation }\end{array}$} & \multicolumn{4}{|c|}{ after immunization with human red cells } \\
\hline & & \multirow[b]{2}{*}{$\begin{array}{l}\text { non- } \\
\text { absorption }\end{array}$} & \multicolumn{3}{|c|}{ absorbed with red cells of } \\
\hline & & & $\begin{array}{l}\text { horse, hog, } \\
\text { dog }\end{array}$ & $\begin{array}{l}\text { horse, hog, dog, } \\
\text { Japanese monkey }\end{array}$ & $\begin{array}{l}\text { horse, hog, dog, } \\
\text { Japanese monkey, } \\
\text { chimpanzee }\end{array}$ \\
\hline human & $1-16$ & $\begin{array}{l}4,096 \\
-16,384\end{array}$ & $\begin{array}{l}1,024 \\
-2,048\end{array}$ & $256-1,024$ & $16-32$ \\
\hline $\begin{array}{l}\text { P. troglodytes } \\
\text { (Chimpanzee) }\end{array}$ & $2-8$ & $16-128$ & $8-64$ & $4-32$ & 0 \\
\hline H. lar & $4-16$ & $8-64$ & $4-16$ & $2-8$ & 0 \\
\hline H. agilis & $2-4$ & $16-64$ & $8-16$ & $2-8$ & 0 \\
\hline $\begin{array}{l}\text { M. fuscata } \\
\text { (Japanese monkey) }\end{array}$ & $1-16$ & $16-128$ & $4-16$ & 0 & 0 \\
\hline M. cyclopis & $2-4$ & $8-32$ & $2-16$ & 0 & 0 \\
\hline M. mulatta & $2-4$ & $8-32$ & $2-16$ & 0 & 0 \\
\hline C. aethiops & $2-4$ & $8-32$ & $2-16$ & $1-4$ & 0 \\
\hline C. (C.) aethiops & $2-16$ & $8-32$ & $2-16$ & $1-4$ & 0 \\
\hline A. paniscus & $2-8$ & $8-32$ & $2-16$ & $1-4$ & 0 \\
\hline L. oedipus & $1-2$ & $8-32$ & $4-8$ & $1-4$ & 0 \\
\hline
\end{tabular}

Characterization of heteroagglutinins of the rabbit anti-human red cell sera:

Heteroagglutinin titers of rabbit anti-human red cell sera (22 cases) ranged $1: 4,096-1: 16,384$ for human, $1: 128$ for dog, horse, hog and guinea pig, and $1: 64$ or less for cat, rat and mouse red cells respectively (Table 1 ). In primates, the tirers were $1: 16-1$ : 128 for chimpanzee and Japanese monkey, and ranged 1:8-1:64 for H.agils, H. lar, M. cyclopis, M. mulatta, C. aethiops, C. $(C)$ aethiops, A. paniscus and L.oedipus, respectively (Table 2). The common agglutinins to animal red cells in the antisera were absorbed with red cells of dog, horse and hog, and the hemagglutinin titers for mammals resulted in $1: 4$ or less, while the titer remained $1: 1,024-1: 2,048$ for human red cells. Further, 9 antisera of which the titers were more than $1: 4,000$ for human red cells were subjected to absorption test with pri- mate red cells. After absorption with red cells of mammals and Japanese monkey, the titers were reduced to $1: 256-1: 1,024$ for human and $1: 1$ $1: 32$ for primate red cells except the macaca. Absorbed antisera with chimpanzee red cells retained specific activity for human red cells ( $\left.1: 16^{-1}: 32\right)$.

\section{The specific antiserum:}

The rabbit anti-human red cell sera absorbed with red cells of horse, hog, dog and Japanese monkey were tested with red cells from 2, 453 human subjects. Agglutinin titers of 1:256 or greater were observed regardless of blood types $\mathrm{ABO}$ and $\mathrm{MN}$.

SDS-PAG electrophoretic pattern of the membrane glycoprotein:

Figure 1 shows SDS-PAG (10\%) electrophoretic pattern stained with the Schiff reagent and the distinctive bands correspond to PAS-1 and PAS-2 
were observed, while an additional faint band correspond to PAS-3 (Fairbanks et al., 1971) was found.

Inhibitory activities of the membrane glycoprotein for the specific antiserum, ant $i-M$ and ant $i-N$ sera:

Five tenth $\mathrm{mg}$ of the membrane glycoprotein clearly inhibited the agglutinating capacity of the specific antiserum (Table 3) as well as anti-M and anti-N sera.

Inhibitory activities of the membrane glycoprotein treated with sialidase for the specific antiserum and anti-M serum:

The results of agglutination inhibition of the specific antiserum and anti-M serum with the membrane glycoprotein treated with sialidase were shown in Table 4 . After $1 \mathrm{hr}$ treatment with sialidase, agglutination inhibition titers for the specific antiserum were the same as the untreated material, but

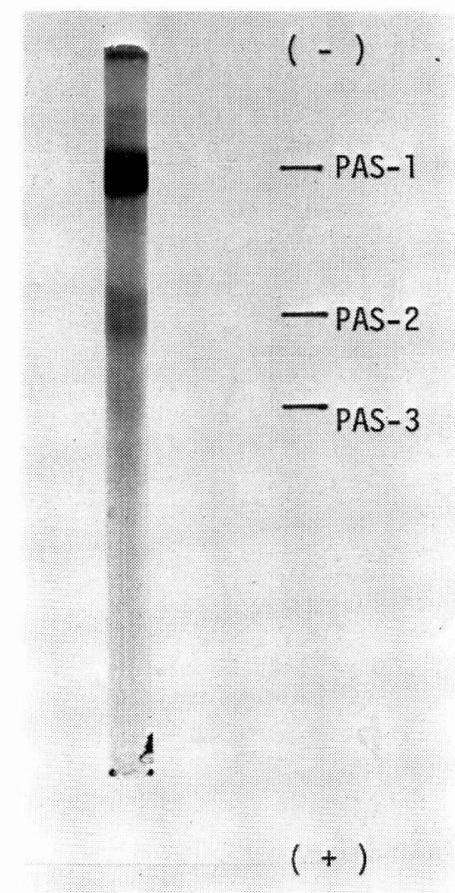

Fig. 1. SDS-PAG (10\%) electrophoresis of the membrane glycoprotein. The gel was stained with PAS.

TABLE 3

Hemagglutination-absorption test of the membrane glycoprotein for the specific antiserum for human red cells

\begin{tabular}{|c|c|c|c|c|c|c|}
\hline \multirow[t]{2}{*}{ absorbed with } & \multicolumn{6}{|c|}{$\begin{array}{l}\text { hemagglutination of human red cells with } \\
\text { the absorbed antiserum } \\
\text { (dilution of the absorbed antiserum) }\end{array}$} \\
\hline & 1 & 2 & 4 & 8 & 16 & 32 \\
\hline the glycoprotein $0.5 \mathrm{mg}$ & - & - & - & - & - & - \\
\hline none & H & H & H & + & - & - \\
\hline
\end{tabular}

TABLE 4

Hemagglutination - inhibition test of the membrane glycoprotein treated with sialidase for the specific antiserum for human red cells and ant $i-M$ serum

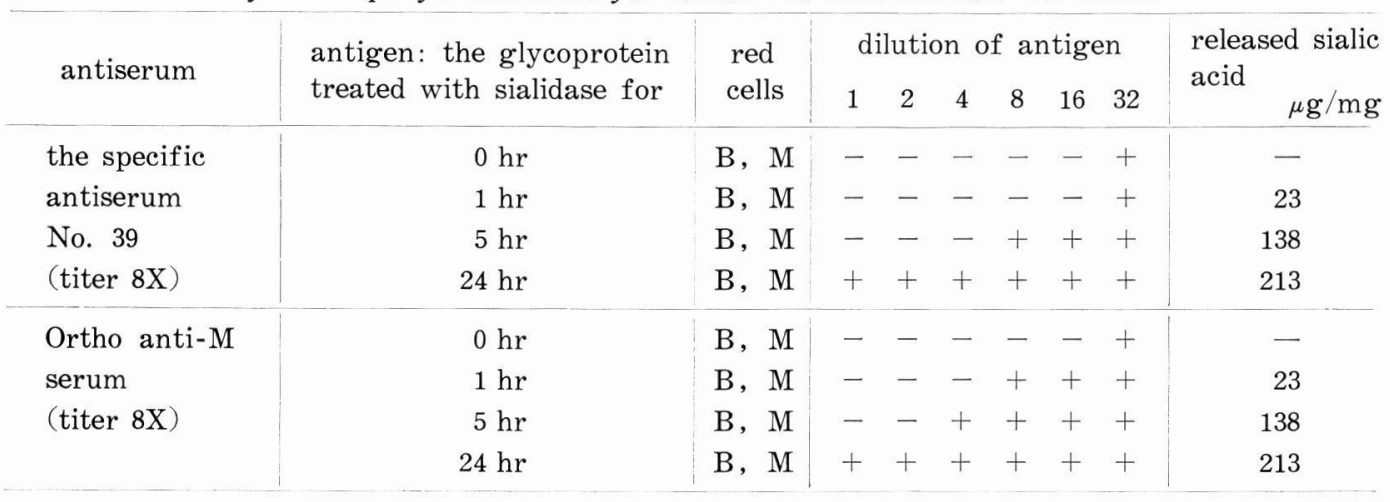


were decreased for anti-M serum ( $1: 16$ to $1: 2$ ). After $5 \mathrm{hr}$ digestion, inhibition titer for the specific antiserum was decreased ( $1: 16$ to $1: 4$ ) and neither the human nor $M$ specific activities of the membrane glycoprotein was detected by agglutination test after $24 \mathrm{hr}$ treament. Sialic acids released from the membrane glycoprotein were $23 \mu \mathrm{g} / \mathrm{mg}, 138 \mu \mathrm{g} / \mathrm{mg}$ and $213 \mu \mathrm{g} / \mathrm{mg}$ after treatment for 1,5 and $24 \mathrm{hr}$, respectively.

\section{DISCUSSION}

In this experiment, specific antiserum against human red cells was prepared in rabbits. Cross-reactivity of heteroagglutinins in rabbit serum before and after immunization of human red cells was tested to human and animal red cells. The results suggest that heteroagglutinins in the rabbit immune serum may be classified into the following three groups: group 1 . these which agglutinate only human red cells, group 2. agglutinate not only human but also animal red cells, and group 3 . agglutinate only animal red cells. The group 2 agglutinins were considered responsible for cross-reactions of the antiserum. Therefore, practical and effective exclusion of the group $2 \mathrm{ag}$ glutinins from the antiserum was required to prepare the specific antiserum.

As the rabbit aniserum demonstrated relatively high agglutinin titers ( 1 : 128) with red cells of horse, hog, dog and the Japanese monkey, they were used for absorption of the group 2 agglutinins. The agglutinin titer of the absorbed antiserum was abolished or negligible for red cells of mammals including the macaca but retained a titer of $1: 256-1: 1,024$ for human red cells. Therefore, the rabbit anti-human red cell serum absorbed with these animal red cells represents the human specific antiserum. In fact, the human specific antiserum was subjected to agglutination test with red cells obtained from 2, 453 persons individually and all cases showed clearly positive agglutination, regardless of blood types $\mathrm{ABO}$ and $\mathrm{MN}$. Furthermore, the human specific antiserum absorbed with red cells of chimpanzee was able to agglutinate human red cells to a titer of $1: 16-1: 32$. The results indicate that the human specific antiserum could be applied for detection of human blood stains with the possibility of discrimination from chimpanzee blood stains.

Many investigators have previously reported that the major sialoglycoprotein (PAS-1 or glycophorin) of the human red cell membrane carries a number of different biological activities including $\mathrm{MN}$ blood group activity (Hamaguchi and Cleve, 1972) and the inhibitory activities against certain lectins (Kornfeld and Kornfeld, 1970; Fukuda and Osawa, 1973; Adair and Kornfeld, 1974). The results of the present studies indicate that the specific antigenic site of human red cells resides in the glycoprotein part of human red cell membranes and the isolated membrane glycoprotein, PAS-1, PAS-2 and PAS-3 on the SDS-PAG electrophoresis, showed inhibitory activities for the specific antiserum as well as anti-M and anti-N sera. But, the band of PAS-3 was faint as shown in the Fig. 1 that the amount of the PAS-3 is considered to be negligible. Therefore, we conclude that the antigenic site for the human specific antiserum resides on the PAS-1.

The chemical differences between the human red cell specific and MN specific activities of the PAS-1 were elucidated by sialidase treatment of the membrane glycoprotein, that is, 1 
$\mathrm{hr}$ digestion led to a decrease in MN specific activity but not in human red cell specific activity, and $24 \mathrm{hr}$ digestion depressed the human specific activity. From these results, we concluded that the sialic acids of the PAS-1 are responsible for both human and MN activities. However, there would be some different structures involving sialic acids in the PAS-1 molecule which may be responsible for the different susceptibilities to sialidase and these structures may reflect different antigenic determinants.

\section{REFERENCES}

Adair, W. L. and Kornfeld, S. (1974). Isolation of the receptors for Weat germ agglutinin and the Ricinus communis lectins from human erythrocytes using affinity chromatography. J. Biol. Chem. 249, 4696-4704.

Dodge, J. T., Mitchell, C. and Hanahan, D. J. (1963). The preparation and chemical characteristics of hemoglobin-free ghosts of human erythrocytes. Arch. Biochem. Biophys. 100, 119-130.

Fairbanks, G., Steck, T. L. and WAllach, D.F.H. (1971). Electrophoretic analysis of the major polypeptides of the human erythrocyte membrane. Biochemistry, 10, 26062617.

Fukuda, M. and Osawa, T. (1973). Isolation and characterization of a glycoprotein from human group 0 erythrocyte membrane. J. Biol. Chem. 248, 5100-5105.

Furthmayr, H., Tomita, M. and Marchesi, V. T. (1975). Fractionation of the major sialoglycopeptides of the human red blood cell membrane. Biochem. Biophys. Res. Commun. 65, 113-121.

HALleN, G. (1929). Zur Isolierung der gruppenspezifischen Antigenemenschlichen Erythrozyten. Z. Immun. Forsch. 63, 287-298.

Hamaguchi, H. and Cleve, H. (1972). Solubilization of human erythrocyte membrane glycoproteins and separation of the MN glycoprotein from a glycoprotein with I, S, and A activity. Biochim. Biophys. Acta, 278, 271-280.

HARA, M. (1974). Forensic immunological studies on human body fluids. Jap. J. Legal Med. 28, 164-176.

Hara, M., Inoue, T., Tsuda, R., Fukuyama, T. and IKI, H. (1976). Forensic immunological studies on the human specific antigen of human red cell membranes. Jap. J. Legal Med. 30, 253-254.

KIRIHAMA, S. (1924). Über die Isohamagglutination beim menschlichem Blute. Zeit. Klin. Med. 99, 522-545.

Kornfeld, R. and Kornfeld, S. (1970). The structure of a phytohemagglutinin receptor site from human erythrocytes. J. Biol. Chem. 245, 2536-2545.

Marchesi, V. T. and Andrews, E. P. (1971). Glycoproteins: Isolation from cell membranes with lithium diiodosalicylate. Science, 174, 1247-1248.

OKuyama, T. and Kondo, M. (1974). SDS-polyacrylamide gel electrophoresis of structural proteins of erythrocyte membrane. Protein, Nucleic Acid and Enzyme, 74, 156-162.

WARREN, L. (1959). The thiobarbituric acid assay of sialic acids. J. Biol. Chem. 234, 19711975.

Weber, K. and Osborn, M. (1969). The reliability of molecular weight determinations by dodecyl sulfate-polyacrylamide gel electrophoresis. J. Biol. Chem. 244, 4406-4412. 